\title{
Jamaica: Employer size and worker remuneration in the private sector
}

\author{
Allister Mounsey
}

ABSTRACT

Evidence suggests that labour markets do not clear as posited by conventional microeconomics.

The enduring inter-industry wage differentials (IIWD) and employer-size wage differentials (ESWD) present a challenge. Data from the Jamaican private sector reveal that ESWD could be the impetus for IIWD. After accounting for labour quality and other characteristics, employers with 10 to 49 employees and 50 or more employees pay estimated premiums of $14.3 \%$ and $22.9 \%$, respectively. After estimating the differences in tenure profiles, the premium associated with the largest employer size was reduced to $15.9 \%$, while the premium associated with establishments of 10 to 49 workers was unchanged. Notwithstanding the partial explanation provided by tenure profile differences, the bulk of the ESWD appears to be explained by other theoretical constructs. 


\section{I}

\section{Introduction}

The existence of positive relationships between the number of workers employed in an establishment and the wages they are paid — the so-called firm-size or employer-size wage differential (ESWD) - is a well documented labour market feature in advanced economies. Lester (1967) was one of the first researchers to comprehensively document the existence of such differentials in the United States. He found that firms with 2,500 workers or more had a combined wage and benefit level that was at least $20 \%$ higher, on average, than businesses with 20 to 100 employees. Masters (1969) demonstrated that the firmsize wage differentials remain after controlling for market competition and unionization. Other authors confirm this phenomenon in the United States (Antos, 1983; Mellow, 1982; Oi, 1983). Winter-Ebmer and Zweimüller (1999) provide evidence of the same phenomenon among small and medium-sized firms in Switzerland, while Fakhfakh and Fitzroy (2006), Oosterbeek and van Praag (1995) and Main and Reilly (1993) find supportive evidence in France, the Netherlands and the United Kingdom, respectively.

Equally as puzzling is the existence of time-invariant inter-industry wage differentials. Slichter (1950, as cited in Krueger and Summers, 1987) has been credited as the first to observe this phenomenon. Slichter found an inter-temporal rank correlation coefficient of 0.73 in the industrial wages of 20 manufacturing industries in the United States over the period 1923 to 1946. Similar findings have been documented both in the United States and internationally (for example, Krueger and Summers, 1987; Gittleman and Wolff, 1993; Arbache, 2001).

The pervasiveness of ESWD and inter-industry wage differentials (IIWD) calls into question the fundamental neoclassical assumption of the existence of marketclearing wages. ESWD, in particular, presents a significant challenge to the conventional theory of the firm, which cannot explain why, according to Lester, would "buyers of labor with the most monopoly power generally pay the highest rates of wage and benefit compensation." For many, these challenges to conventional understandings of labour markets and how firms operate remain unanswered despite attempts to explain them within the competitive profit-maximizing framework of neoclassical economics.

The persistently high levels of unemployment in the Caribbean intensify the need for investigating such phenomena in the region. ${ }^{1}$ While inter-industrial wage differentials have received some attention in the Englishspeaking Caribbean (Mounsey and Polius, 2011), the phenomenon of firm-size wage differential has not been investigated. This paper aims to provide a base for further investigation by presenting evidence for the existence of ESWD and IIWD in Jamaica. It demonstrates that the observed IIWD could, in principle, be explained by the share of the total industry labour force employed by large or small establishments, which raises the possibility that ESWD is the cause of IIWD. ${ }^{2}$ It also examines the extent to which explanations based on labour quality and differences in tenure profiles can account for the estimated firm-size wage premiums.

The remainder of paper is divided into five sections. Section II provides a review of some of the theoretical explanations for employer-size wage differentials (ESWD). The data used are outlined in the following section. Section III presents evidence for the interrelatedness of ESWD and IIWD; the estimation and results are presented in section IV; and section V concludes the paper.

\footnotetext{
1 Data from the International Labour Organization (ILO) reveal that the unemployment rate in Barbados, Jamaica and Trinidad and Tobago averaged $8.6 \%, 10.8 \%$ and $6.5 \%$ per year, respectively, in 2004-2008 (countries selected based on data availability).

2 The paper does not examine the temporal stability of either IIWD or ESWD in Jamaica, because of time series limitations in the data set.
} 


\section{II}

\section{Theoretical explanations of ESWD}

Explanations of ESWD belong to one of two broad categories: competitive and non-competitive explanations. The latter holds that institutional characteristics endogenous to firms of a particular size result in workers of comparable skill and experience being remunerated at different rates based on the size of the employer. In the case of the former, the firms of differing sizes are posited as offering differing working conditions and/ or requiring differing worker quality. Workers must be compensated for these differences (working conditions and/or worker quality), resulting in observed firm-size wage differentials.

\section{Competitive explanations: compensating differentials}

The quintessential summary of the theory of compensating differentials is found in Smith (1904), who had made the point in the first edition published in 1776: "The wages of labour vary with the ease or hardship, the cleanliness or dirtiness, the honourableness or dishonourableness of the employment." The theory of compensating differentials therefore posits that firm-size wage differentials exist because of size differentials in working conditions or labour quality.

Working conditions explanations, which are not pursued in this paper because of data limitations, focus on the undesirable aspect of working in large firms, such as the rules-oriented environment and the lack of control over one's action and schedule (Master, 1969; Duncan and Stafford, 1980). The labour quality explanation holds that larger firms actively seek higher quality workers compared with other firms. A possible motivation for this is that larger firms tend to adopt more capital-intensive technologies, and highly skilled labour is complementary to capital (Hamermesh and Grant, 1979). Capital-skill complementarities therefore cause larger, more capital intensive firms to disproportionately employ more highly skilled workers who command a market-determined premium.

Rosen (1982) advanced an alternative motivation based not so much on the skill of the typical worker, but rather on the talent resident in top positions in large firms vis-à-vis smaller firms. Rosen posits that the increase in productivity that results from assigning persons of superior talent to top positions is greater than the increment of their abilities because talent filters through the entire command chain below them. In such a situation, the competitive market for managers and supervisors will equilibrate in the top positions in large firms being filled with highly talented individuals who are also highly rewarded, while the top positions in smaller firms are filled by less talented, lower-paid individuals.

Yet another motivation is provided by the monitoring cost hypothesis of Oi (1983). Entrepreneurs have identical abilities in terms of monitoring workers; they differ, however, in their capacity to coordinate production. Time constraints therefore result in a relatively high shadow cost associated with monitoring by more talented entrepreneurs, who are assumed to head larger firms. Entrepreneurs in large firms seek to minimize the high shadow cost of monitoring workers by employing higherquality workers, who are more productive, require less monitoring per efficiency unit of labour and command a market-determined wage premium based their superior quality.

Proponents of labour quality explanations to ESWD are quick to point out that quality is composed of both measured characteristics, such as education and experience, and unmeasured qualities. The former is easily tested using widely available cross-sectional data sets, whereas testing the importance of unmeasured quality typically requires more expensive, less available longitudinal data (Brown and Medoff, 1989).

\section{Non-competitive explanations}

There are several non-competitive explanations of ESWD. Broadly speaking, they can be divided into those that are consistent with the assumption of profit-maximizing (cost-minimizing) firms and those that are not. With respect to the latter, probably the best known of these is the product market power hypothesis ( $\mathrm{PMPH})$, which states that firms with monopoly power (namely, larger firms) use some of their excess profit to engage in some degree of rent sharing with their workers (Brown and Medoff, 1989). One of the major challenges faced by the PMPH is its inability to explain why competition for these preferred jobs does not create an overqualified but not overpaid workforce (Brown and Medoff, 1989).

Among the explanations consistent with profit maximization are efficiency wage models and explanations 
based on differences in tenure-wage profiles between larger and smaller firms. The remainder of this subsection provides brief summaries of each of these noncompetitive explanations.

Riveros and Bouton (1994) define efficiency wage models as "a family of conceptually distinct theories that, for the most part, seek to offer an [endogenously determined] explanation of persistent real wage rigidities in the presence of involuntary unemployment. The central assumption of these theories is that higher real wages can, through various mechanisms, result in higher labour productivity." There are three main efficiency wage models: (i) the monitoring and shirking model; (ii) the turnover cost model; and (iii) the sociological model. The next three paragraphs outline each of these in turn (adapted from Mounsey and Polius, 2011).

(i) Shapiro and Stiglitz (1984) demonstrated that under conditions of imperfect monitoring, the basic neoclassical competitive paradigm produces equilibrium where all workers will shirk. To illicit greater effort from employees, firms pay more than the market-clearing wage, thereby instituting a penalty for an employee who is caught shirking and is fired. ${ }^{3}$ Bulow and Summers (1986) extended the basic Shapiro-Stiglitz framework to show how equally productive workers can, in equilibrium, be arbitrarily allocated between a high-wage and lowwage sector, where the high-wage firms are those for whom shirking is most costly and/or monitoring is most difficult. In the context of firm size, proponents argue that monitoring is more difficult and shirking is possibly more costly in larger firms.

(ii) The turnover cost model postulates that when workers quit, firms incur sunk costs associated with hiring replacements, training new workers and suffering a loss in productivity as new workers move along the learning curve. Firms try to minimize these turnover costs by paying a wage premium to encourage longer employment spells (Salop, 1979). Proponents argue that for any given occupation, turnover costs may vary positively with firm size, as larger firms tend to use more specialized production techniques and thus invest more per worker in training. This creates a wage distribution that also correlates positively with firm size.

(iii) Akerlof (1982 and 1984) argues that social conventions, or norms, at the work place have a strong effect on workers' attitudes. Workers are motivated to work hard because they acquire sentiment for each other and for the firm. In return for their commitment,

3 The extent of the wage premium is dependent on the cost of shirking to the firm. workers expect to be reciprocated with fair wages. This fair wage depends on the wages of workers in the workers' reference group and past wages, among other things. According to the basic sociological model, "the loyalty of workers is exchanged for high wages, and this loyalty can be translated via effective management into high productivity" (Akerlof, 1984, p. 80). Inter-firm (inter-industry) wage differentials can be explained by the differing ability of firm (industries) to translate employee loyalty into higher productivity.

Another explanation for positive firm-size wage differentials is differences in the tenure profile of large versus small firms. Large firms, it is argued, make heavier investment in industry-specific training than do small firms. Large employers thus have a vested interest in retaining their employees. One way of retaining workers is through the use of seniority wage, where worker wages increase with years in the company (Lazear, 1979 and 1981). This creates a tenure profile (of wages) and introduces an element of deferred compensation, almost equivalent to the worker posting a bond with the firm. The workers' incentive structure is therefore altered, inducing them to work harder and remain honest with the firm in order to finally reach the pay-back period of the bond (Zwick, 2009). ${ }^{4}$ The large firms' vested interest therefore results in steeper tenure profiles for larger firms and may explain firm-size wage differentials.

\section{Study data}

The data for this paper is sourced from the Jamaica Labour Force Survey (JLFS), conducted quarterly by the Statistical Institute of Jamaica (STATIN). The paper uses the JLFS for the second quarter of each year from 2004 to 2007. The selected variables were extracted for respondents indicating that they were employed in the private sector during the reference period of the respective survey. ${ }^{5}$ These respondents amounted to 7,667 persons, representing approximately $74.7 \%$ of the employed persons in the survey. A breakdown of the pooled sample over the period under consideration is given in table $1 .^{6}$

\footnotetext{
4 The existence of tenure profiles can also be motivated from a monitoring perspective (see Pearce, 1990; Zwick, 2009).

5 Own-account workers, unpaid family workers and employers were also excluded.

6 The choice of the second quarter was entirely arbitrary; however, the same quarter was selected for several years rather than, say, four quarters in one year so as to mitigate the impact of seasonality in the regressors.
} 
TABLE 1

\section{Temporal breakdown of the sample}

\begin{tabular}{llllll}
\hline \multirow{2}{*}{ Sample } & \multicolumn{4}{c}{ Period (second quarter) } & \multirow{2}{*}{ Total } \\
\cline { 2 - 5 } & 2004 & 2005 & 2006 & 2007 & \\
\hline Number surveyed & 2131 & 1765 & 2016 & 1755 & 7667 \\
\hline
\end{tabular}

Source: prepared by the author on the basis of data from the Jamaica Labour Force Survey, second quarter, 2004 to 2007, Statistical Institute of Jamaica (STATIN).

The variables used in this paper are the worker's main occupation group (OCC), main industry group (IND), tenure or time in the current job (TEN), log of gross annual earnings from main job (LAE), years of experience (EXP), years of effective schooling (YS), gender (GEN) and regular hours worked per week (HWKD). Additional information used includes whether or not the worker has received formal on-the-job training (OJT), whether or not her educational attainment allowed her to at least matriculate in tertiary studies (TMAT) ${ }^{7}$ the size of the employer, measured as the number of persons employed at the worker's main workplace (ES) and whether the workplace is located in the capital Kingston, a rural area or an urban area (KRU). ${ }^{8}$

7 That is, the worker has obtained at least five Ordinary Level $(\mathrm{O}$ Level) passes, which is the typical entry requirement for Advanced Level (A Level) studies. For those unfamiliar with the British based education system, A Level studies are roughly equivalent to a college diploma in the United States education system. The rationale for the inclusion of TMAT is to make a quality distinction among the $46.2 \%$ of the sample with 11 years of schooling (completed secondary school). 8 Variables in italics represent those that have been transformed from original variables. ES was originally a five-category variable; for the sake of parsimony it was reduced to three categories by collapsing the first three categories. TEN is a three-category variable translating to less than two years, two to five years and more than five years in current job. The original categorical variable from which it is derived has seven categories (four of which relate to persons working with their current employer for less than one year.
The variables YS, LAE and EXP were obtained from the following transformations to original JLFS variables. The transformations are described below:

$$
Y S=\left\{\begin{array}{c}
16, \text { if } \text { Hcert }=\text { Degree } \\
13, \text { if Hcert }=\text { A'levels } \\
P+S, \text { otherwise }
\end{array}\right.
$$

where Hcert is the highest certification attained and $P$ and $S$ are years of primary and secondary school education, respectively.

$$
E X P=A G E-Y S-5
$$

where $A G E$ is the individual's age in years, which is obtained from the JLFS.

$$
L A E=\ln G A E
$$

where GAE is the worker's gross annual earnings from her main occupation, as computed from in the JLFS. ${ }^{9}$

Table 2 shows the distribution of survey respondents by industry and firm size. As can be expected of a service-oriented economy, the sample at the industrial level is heavily concentrated in the community, social and personal services sector and the wholesale and retail and hotel and restaurant sector. At the firm level, more than half of the private sector workers are employed in firms with nine people or fewer, which again is consistent with the country's service-oriented nature.

9 Each respondent's earnings were reported for one of three periodicities (weekly, monthly or yearly). Where earnings were reported on a weekly or monthly basis, they were multiplied by 52 and 12 respectively to convert to yearly earnings. 


\begin{tabular}{|c|c|c|c|c|}
\hline \multirow{2}{*}{ Industry group (one digit) } & \multicolumn{3}{|c|}{$\begin{array}{c}\text { Firm size } \\
\text { (number of workers) }\end{array}$} & \multirow{2}{*}{ Total } \\
\hline & $<10$ & $10-49$ & $\geq 50$ & \\
\hline Agriculture, forestry and fishing (1) & 191 & 118 & 84 & 393 \\
\hline Construction and installation (2) & 683 & 281 & 53 & 1017 \\
\hline Community, social and personal services (3) & 1704 & 263 & 64 & 2031 \\
\hline Electricity, gas and water (4) & 2 & 12 & 17 & 31 \\
\hline Finance, insurance, real estate and business services (5) & 106 & 313 & 225 & 644 \\
\hline Mining, quarrying and refining (6) & 3 & 25 & 93 & 121 \\
\hline Manufacturing (7) & 182 & 295 & 224 & 701 \\
\hline Transportation, storage and communications (8) & 277 & 116 & 110 & 503 \\
\hline Wholesale, retail, hotels and restaurants (9) & 748 & 782 & 342 & 1872 \\
\hline Total & 3896 & 2205 & 1212 & 7313 \\
\hline
\end{tabular}

Source: prepared by the author on the basis of data from the Jamaica Labour Force Survey, second quarter, 2004 to 2007, Statistical Institute of Jamaica (STATIN).

Note: firm size was not stated in 354 responses.

\section{III}

\section{The interrelatedness of employer-size wage differentials and inter-industry wage differential}

This section presents a brief statistical investigation of inter-industry wage differentials and employer-size wage differentials. Let $G A E_{i j k t}$ stand for the reported annual income of individual $i$ in occupation $j$ working in industry $k$ at year $t$. The hourly wage received by this individual will be approximated as follows: ${ }^{10}$

$$
w_{i j k t}=\frac{G A E_{i j k t}}{52(H W K D)}
$$

Data on occupation is provided at the four-digit level. The mean hourly wage for each four-digit occupation code is calculated for each year using the following formula:

$$
\overline{w_{j k t}}=\frac{\sum_{\forall i i n t} w_{i j k t}}{n_{j t}}
$$

where $n_{j t}$ is the number of individuals in occupation $j$ at year $t$.

${ }^{10}$ Information on actual weeks worked per year is not available in the data set, so for the purposes of estimating hourly wage, the number of weeks worked by each worker is assumed to be constant (at 52 weeks per year).
Finally the worker's relative wage $(r w)$ (relative to the average wage received by the occupational cohort) is calculated as follows:

$$
r w_{i j k t}=w_{i j k t} / \frac{}{w_{j k t}} \forall i \text { and } t
$$

Table 3 shows the distribution of mean relative wage $\left(\overline{r w_{k}}\right)$ by industry group and employer size. ${ }^{11} \mathrm{~A}$ mean relative wage $\left(\overline{r w_{k}}\right)$ of less than one (say, 0.75 ) means that a randomly selected worker in industry $\mathrm{k}$ can expect to receive an hourly wage that is $25 \%$ less than the average for the occupation. If $\overline{r w_{k}}>1$, then industry $k$ on average pays [( $\left.\left.\overline{r w_{k}}-1\right) \times 100\right]$ per cent more to its workers relative to their occupational averages.

11 The mean relative wage of industry $\mathrm{k}$ is given by:

$$
\overline{r w_{k}}=\sum_{i} r w_{i j k t} / N_{k} \quad \forall i \text { in } k
$$

where $N_{k}$ is the number of sample elements in industry $k$. A similar calculation is used to obtain the mean relative wage by employer size in industry group $k$. 
TABLE 3

Mean relative wage $\left(\overline{r w}_{k}\right)$ by industry group and firm size

\begin{tabular}{|c|c|c|c|c|}
\hline \multirow{2}{*}{ Industry group (one-digit level) } & \multicolumn{3}{|c|}{$\begin{array}{c}\text { Firm size } \\
\text { (number of workers) }\end{array}$} & \multirow{2}{*}{ All firms } \\
\hline & $<10$ & $10-49$ & $\geq 50$ & \\
\hline Agriculture, forestry and fishing (1) & 0.951 & 1.011 & 0.972 & 0.973 \\
\hline Construction and installation (2) & 0.951 & 1.062 & 1.206 & 0.995 \\
\hline Community, social and personal services (3) & 0.966 & 1.011 & 1.059 & 0.974 \\
\hline Electricity, gas and water (4) & 1.203 & 1.041 & 1.342 & 1.217 \\
\hline Finance, insurance, real estate and business services (5) & 0.943 & 1.108 & 1.299 & 1.148 \\
\hline Mining, quarrying and refining (6) & 0.695 & 0.879 & 1.363 & 1.247 \\
\hline Manufacturing (7) & 0.874 & 1.037 & 1.134 & 1.026 \\
\hline Transportation, storage and communications (8) & 0.909 & 1.028 & 1.229 & 1.007 \\
\hline Wholesale, retail, hotels and restaurants (9) & 0.827 & 0.999 & 1.101 & 0.949 \\
\hline All industry groups & 0.927 & 1.030 & 1.172 & 1.000 \\
\hline
\end{tabular}

Source: prepared by the author on the basis of data from the Jamaica Labour Force Survey, second quarter, 2004 to 2007 , Statistical Institute of Jamaica (STATIN).

The data in tables 2 and 3 raise the question of whether the percentage of the industry labour force employed in the largest or smallest firm-size category explains the industrial distribution of $\overline{r w_{k}}$. For all but one industrial group, $\overline{r w_{k}}$ is greater than one for the largest firm-size category and less than one for the smallest (see table 3). Furthermore, industries with $\overline{r w_{k}}>1$ tend to have a greater concentration of its workforce employed by larger firms, and industries with $\overline{r w_{k}}<1$ tend to a larger concentration of workers in smaller firms (see table 2 and table 3 ).

Table 4 provides strong support for this hypothesis, as measures of parametric and non-parametric correlation indicate a high positive correlation between workforce concentration in large firms and industry mean relative wages $\left(\overline{r w_{k}}\right)$, while simultaneously finding a strong negative correlation between small-firm workforce concentration and industry mean relative wages.

TABLE 4

Pearson's and Spearman's rank correlation between $\overline{r w_{k}}$ and concentration of workers in select firm sizes

\begin{tabular}{|c|c|c|c|c|c|c|}
\hline \multirow{2}{*}{ Industry group } & \multicolumn{2}{|c|}{$\begin{array}{c}\text { Share of workers by firm size } \\
\text { (Percentages) }\end{array}$} & \multirow{2}{*}{$\begin{array}{c}\text { Rank } \\
\text { (A) }\end{array}$} & \multirow{2}{*}{$\begin{array}{c}\text { Rank } \\
\text { (B) }\end{array}$} & \multirow{2}{*}{$\frac{\text { Industry }}{r w_{k}}$} & \multirow{2}{*}{$\frac{\operatorname{Rank}}{\left(\overline{r w_{k}}\right)}$} \\
\hline & $\begin{array}{l}50 \text { or more } \\
\text { workers } \\
\text { (A) }\end{array}$ & $\begin{array}{l}10 \text { or fewer } \\
\text { workers } \\
\text { (B) }\end{array}$ & & & & \\
\hline Agriculture, forestry and fishing (1) & 21.4 & 48.60 & 4 & 6 & 0.973 & 2 \\
\hline Construction and installation (2) & 5.2 & 67.16 & 2 & 8 & 0.995 & 4 \\
\hline Community, social and personal services (3) & 3.2 & 83.90 & 1 & 9 & 0.974 & 3 \\
\hline Electricity, gas and water (4) & 54.8 & 6.45 & 8 & 2 & 1.217 & 8 \\
\hline Finance, insurance, real estate and business services (5) & 34.9 & 16.46 & 7 & 3 & 1.148 & 7 \\
\hline Mining, quarrying and refining (6) & 76.9 & 2.48 & 9 & 1 & 1.247 & 9 \\
\hline Manufacturing (7) & 32.0 & 25.96 & 6 & 4 & 1.026 & 6 \\
\hline Transportation, storage and communications (8) & 21.9 & 55.07 & 5 & 7 & 1.007 & 5 \\
\hline Wholesale, retail, hotels and restaurants (9) & 18.3 & 39.96 & 3 & 5 & 0.949 & 1 \\
\hline Pearson's correlation with $\overline{r w_{k}}$ & 0.908 & -0.828 & & & & \\
\hline Spearman's correlation with $\overline{r w_{k}}$ & & & 0.867 & -0.733 & & \\
\hline
\end{tabular}

Source: prepared by the author on the basis of data from the Jamaica Labour Force Survey, second quarter, 2004 to 2007, Statistical Institute of Jamaica (STATIN). 
The size of the positive (negative) correlation between the workforce concentration in the largest (smallest) employer-size category and industry mean relative wage $\left(\overline{r w_{k}}\right)$, suggests an interrelation between employer-size wage differentials and inter-industry wage differentials. Furthermore, the fact that $\overline{r w_{k}}$ is greater than one (less than one) for large firms (small firms) in all but one industry group suggests that causality runs from ESWD to IIWD and not the other way around.

\section{IV}

\section{Estimation and results: explaining ESWD}

Table 3 suggests that after controlling for occupational characteristics, workers in establishments with fewer than 10 workers receive an hourly wage that is $24.6 \%$ less, on average, than the average wage of workers in firms with 50 or more employees. This analysis, while useful, is somewhat limited, in that it does not control for other worker characteristics, such as experience and years of schooling, and it does not provide an explanation for the ESWD phenomenon. Both shortcomings can to some extent be overcome by examining the magnitude and statistical significance of the employer size (ES) coefficients, $\alpha_{k}$ in the augmented human capital equation (1):

$$
\begin{gathered}
L A E=\alpha+\sum_{h=1}^{4} \alpha_{h} Y E A R_{h}+b_{2} H W K D+b_{3} H W K D^{2}+ \\
b_{4} E X P+b_{5} E X P^{2}+b_{6} Y S+b_{7} Y S^{2}+b_{8} T M A T \times Y S+ \\
b_{9} T M A T \times Y S^{2}+\alpha_{1} T M A T+\sum_{i=1}^{8} \alpha_{i} O C C_{i}+ \\
\sum_{i=1}^{8} \alpha_{i, 1} O C C_{i} O J T+\sum_{i=1}^{8} \alpha_{i, 2} O C C_{i} G E N+ \\
\sum_{j=1}^{8} \alpha_{j} I N D_{j}+\sum_{k=1}^{2} \alpha_{k} E S_{k}+\sum_{l=1}^{2} \alpha_{l} T E N_{l}+ \\
\sum_{m=1}^{2} \alpha_{m} K R U_{m}
\end{gathered}
$$

where $\alpha$ is the main intercept parameter; $\alpha_{j}$ is the intercept-shift parameter of the $j$ th dummy variable in the associated dummy variable group, $\forall h, i, j, m ; \alpha_{j l}$ is a further shift parameter resulting from the interaction of the $j$ th and $l$ th dummy variables in their respective dummy groups, $\forall j, l$; and $\mathrm{b}_{i}$ is the slope parameter for its associated variable, $\forall \mathrm{I}=1,2, \ldots, 9$.

Equation (1) includes several variables that provide an indication of worker quality, namely, experience (EXP), years of schooling (YS), whether the worker matriculated or could have matriculated in a tertiary educational institution (TMAT), and whether the worker received formal on the job training (OJT).
If it is determined that both firm-size interceptshift parameters are individually equal to zero $\left(\alpha_{k}\right.$ $=0$ ), then it can be inferred that (measured) labour quality explanations (LQE) can account the estimated ESWD (see table 3). However, should it be determined that at least one $\alpha_{k} \neq 0$ (an employer-size premium, or ESP), a modification of equation (1) will be estimated to determine the appropriateness of incorporating firm-size differences in tenure profiles as a supporting explanation of ESWDS. This involves incorporating a size-tenure interaction dummy variable, that is, adding $\sum_{l=1}^{2} \sum_{k=1}^{2} \alpha_{l k} T E N_{l} E S_{k}$ to equation (1).

All estimations used the STATA-12.1 statistical software. When equation (1) is estimated using ordinary least squares (OLS), the test for the presence of influential outliers suggests that 338 such observations exist in the data set (of 7,186 complete sets of observations), possibly contributing to the relatively low explanatory power of the model ( $R$ squared of 0.397). ${ }^{12}$ There are two available courses of actions: (i) use a robust or highbreakdown estimation technique (values to outliers); or (ii) eliminate some or all of the observations identified as influential outliers. The latter course of action is advisable if the outliers are clearly the result of a spurious activity (Cousineau and Chartier, 2010; Osborne and Overbay, 2004). While robust estimation techniques in principle protect parameter estimates from being distorted in the presence of outliers without the risk associated with eliminating outlying observations, it does not give equal weight to each observation in the regression, thereby introducing some degree of value judgement. ${ }^{13}$

The results presented in this paper are based on the original sample of 7,186 observations minus 36 of the

\footnotetext{
12 Influential outliers were identified using Cook's distance influence statistic with the conventional cut off $(4 / n)$.

13 See Verardi and Croux (2009) for a technical exposition on the various types of robust regression techniques.
} 
338 influential outliers. The process involved in selecting these 36 outliers is briefly outlined below.

Figure 1 plots the log of gross annual earnings from main job (LAE) and $r w$ for the 338 influential outliers in the model. ${ }^{14}$ I refer to these outliers, identified both by the regression model (influential outliers) and by the distribution of $r w$, as double outliers. Eight of the 36 double outliers are low outliers, while 28 are high outliers.

All 36 double outliers were taken to be "illegitimately included in the data" (Osborne and Overbay, 2004) and were therefore removed. In total, 36 influential outliers

14 The high and low outlier marks of the $r w$ sample distribution were identified by first transforming $r w$ using the modified square root transformation, as proposed by Cousineau and Chartier (2010):

$$
r w^{\prime}=\sqrt{\frac{r w-r w_{l}}{r w_{h}-r w_{l}}}
$$

where $r w_{h}$ and $r w_{l}$ are the highest and lowest values of $r w$. This transformation converted the right-skewed distribution ( $r w$ ) to a symmetric distribution $\left(r w^{\prime}\right)$. A conventional boxplot was used to identify severe outlier boundaries for the $r w^{\prime}$ distribution. Appropriate transformations were made to convert these $r w^{\prime}$ outlier boundaries to outlier boundaries for the original $r w$ distribution. were dropped. ${ }^{15}$ The remainder of the original 338 influential outliers were retained in the data set.

Table 5 shows the estimation results of equation (1). The estimation is based 7,150 observations following removal of the 36 double outliers. Approximately $46.8 \%$ of the variation in the log annual earnings is explained by the model. When the 36 double outliers are included in the data set (7,186 observations), the regressions results (not shown is this paper) were quite similar to table 5 , with an R squared of $39.7 \%$. The robust regression (not shown) also produces similar results.

15 The outlier cut-offs for $r w$ are 0.004068 on the low end and 3.416260 on the high end. Double outliers are those outliers that have been identified by the model as being highly influential and whose hourly wage is either less than $0.4 \%$ of their occupational averages or more than $242 \%$ over the mean earnings for their fourdigit occupation code. On the low end, seven of the eight individuals reported earnings of less than US\$ 3 per year. Of the 28 high double outliers, the individuals earn, on average, 5.7 times the mean wages for their respective four-digit occupation group, with the first quartile earning between 3.5 and 3.6 times their occupation mean earnings and the last quartile earning over 7.8 times their occupational mean, with one person reportedly making an annual income of over US\$21 million (23.8 times the average wage for the occupation). In these observations, either the reported income or the occupational code is likely to be misrepresented (deliberately or otherwise).

FIGURE 1

Plot of $r w$ and LAE for influential outliers

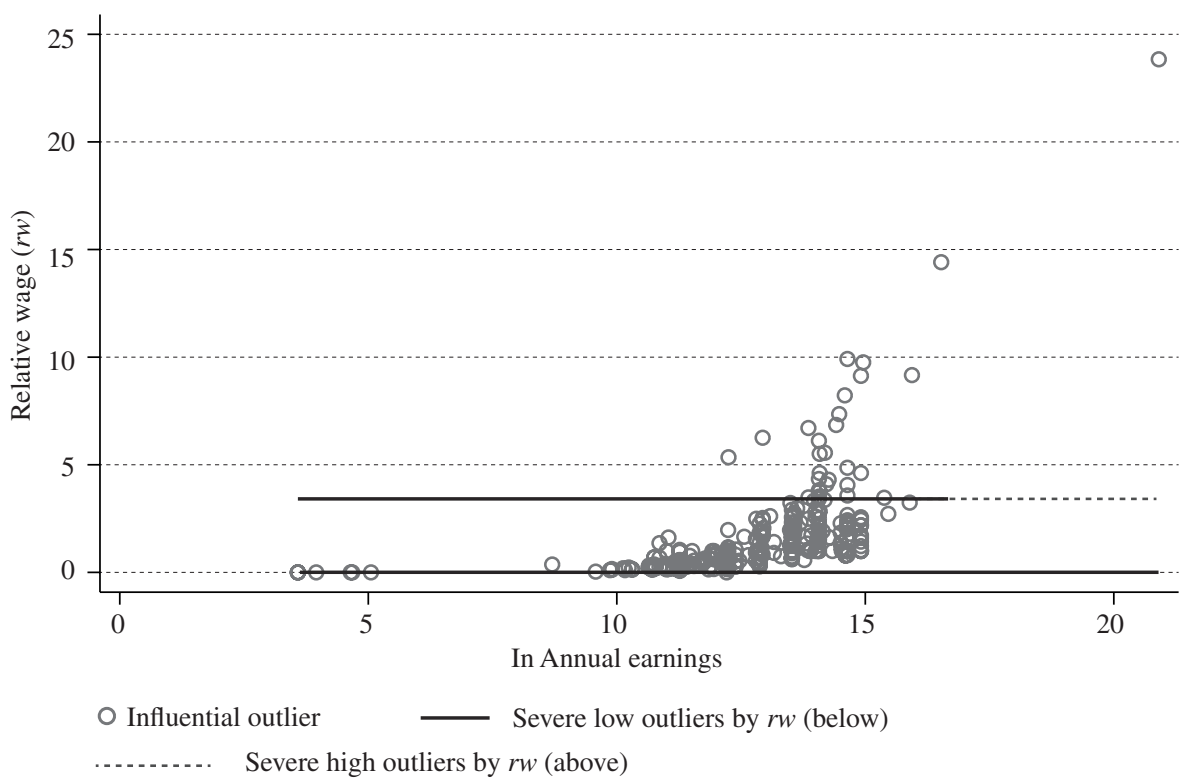

Source: prepared by the author on the basis of data from the Jamaica Labour Force Survey, second quarter, 2004 to 2007, Statistical Institute of Jamaica (STATIN).

Note: points below the solid line indicate relative wages $(r w)$ that are lower than the low outlier mark in the $r w$ distribution; points above the dashed line represent relative wages $(r w)$ that are higher than the high outlier mark in the $r w$ distribution.

LAE: $\log$ of gross annual earnings from main job. 
The coefficients are generally of the expected sign. The returns on experience is concave (increasing at a decreasing rate), as is the return on hours worked.
People who have worked for five or more years with their current firm earn a premium of $9.1 \%$ over workers with tenure of two years or less.

TABLE 5

Estimation output: equation (1)

\begin{tabular}{|c|c|c|c|c|c|c|}
\hline Explanatory variable & Coefficient & Std. Error & $t$ statistic & $P>|t|$ & \multicolumn{2}{|c|}{$95 \%$ Conf. Interval } \\
\hline \multicolumn{7}{|l|}{ YEAR } \\
\hline 2005 & 0.0906 & 0.0148 & 6.14 & 0.0000 & 0.0616 & 0.1195 \\
\hline 2006 & 0.1824 & 0.0143 & 12.74 & 0.0000 & 0.1543 & 0.2104 \\
\hline 2007 & 0.2343 & 0.0158 & 14.84 & 0.0000 & 0.2033 & 0.2652 \\
\hline \multicolumn{7}{|l|}{ IND } \\
\hline 2 & 0.3073 & 0.0325 & 9.45 & 0.0000 & 0.2435 & 0.3711 \\
\hline 3 & 0.0538 & 0.0310 & 1.74 & 0.0820 & -0.0069 & 0.1146 \\
\hline 4 & 0.5445 & 0.1054 & 5.17 & 0.0000 & 0.3380 & 0.7510 \\
\hline 5 & 0.2609 & 0.0363 & 7.19 & 0.0000 & 0.1898 & 0.3321 \\
\hline 6 & 0.6126 & 0.0544 & 11.26 & 0.0000 & 0.5060 & 0.7192 \\
\hline 7 & 0.1364 & 0.0341 & 4.00 & 0.0000 & 0.0696 & 0.2033 \\
\hline 8 & 0.1892 & 0.0374 & 5.06 & 0.0000 & 0.1160 & 0.2625 \\
\hline 9 & 0.0700 & 0.0303 & 2.31 & 0.0210 & 0.0105 & 0.1295 \\
\hline \multicolumn{7}{|l|}{ OCC $^{a}$} \\
\hline 3 & 0.1373 & 0.0526 & 2.61 & 0.0090 & 0.0342 & 0.2404 \\
\hline 4 & -0.0988 & 0.0503 & -1.97 & 0.0490 & -0.1974 & -0.0003 \\
\hline 5 & 0.3066 & 0.0921 & 3.33 & 0.0010 & 0.1262 & 0.4871 \\
\hline 6 & -0.1336 & 0.0609 & -2.19 & 0.0280 & -0.2529 & -0.0143 \\
\hline 7 & 0.4889 & 0.1095 & 4.46 & 0.0000 & 0.2742 & 0.7037 \\
\hline 8 & -0.2415 & 0.1506 & -1.60 & 0.1090 & -0.5368 & 0.0537 \\
\hline 9 & -0.0249 & 0.0510 & -0.49 & 0.6250 & -0.1248 & 0.0750 \\
\hline 10 & 0.1150 & 0.0665 & 1.73 & 0.0840 & -0.0153 & 0.2453 \\
\hline HWKD & 0.0226 & 0.0051 & 4.41 & 0.0000 & 0.0126 & 0.0326 \\
\hline $\mathrm{HWKD}^{2}$ & -0.0002 & 0.0001 & -3.55 & 0.0000 & -0.0003 & -0.0001 \\
\hline \multicolumn{7}{|l|}{ ES } \\
\hline $10-49$ workers & 0.1432 & 0.0133 & 10.73 & 0.0000 & 0.1170 & 0.1693 \\
\hline$\geq 50$ workers & 0.2285 & 0.0183 & 12.48 & 0.0000 & 0.1926 & 0.2643 \\
\hline EXP & 0.0119 & 0.0017 & 7.13 & 0.0000 & 0.0086 & 0.0151 \\
\hline $\operatorname{EXP}^{2}$ & -0.0001 & 0.0000 & -5.08 & 0.0000 & -0.0002 & -0.0001 \\
\hline TMAT & -0.8870 & 1.9454 & -0.46 & 0.6480 & -4.7006 & 2.9265 \\
\hline YS & 0.0343 & 0.0224 & 1.53 & 0.1260 & -0.0097 & 0.0783 \\
\hline TMAT\#YS $^{\text {b }}$ & 0.1623 & 0.2998 & 0.54 & 0.5880 & -0.4253 & 0.7499 \\
\hline $\mathrm{YS}^{2}$ & 0.0002 & 0.0013 & 0.12 & 0.9010 & -0.0024 & 0.0027 \\
\hline TMAT\#YS $^{2}$ & -0.0053 & 0.0112 & -0.47 & 0.6360 & -0.0273 & 0.0167 \\
\hline \multicolumn{7}{|l|}{ OCC\#OJT ${ }^{b}$} \\
\hline $2 \# 1$ & 0.0742 & 0.0289 & 2.57 & 0.0100 & 0.0176 & 0.1309 \\
\hline $3 \# 1$ & 0.1522 & 0.0343 & 4.44 & 0.0000 & 0.0850 & 0.2194 \\
\hline $4 \# 1$ & 0.1777 & 0.0576 & 3.08 & 0.0020 & 0.0647 & 0.2907 \\
\hline $5 \# 1$ & 0.3549 & 0.1063 & 3.34 & 0.0010 & 0.1464 & 0.5633 \\
\hline $6 \# 1$ & -0.0127 & 0.0643 & -0.20 & 0.8430 & -0.1388 & 0.1133 \\
\hline $7 \# 1$ & -0.0137 & 0.0993 & -0.14 & 0.8910 & -0.2084 & 0.1811 \\
\hline $8 \# 1$ & 0.2617 & 0.0843 & 3.11 & 0.0020 & 0.0965 & 0.4268 \\
\hline $9 \# 1$ & 0.1057 & 0.0244 & 4.33 & 0.0000 & 0.0578 & 0.1537 \\
\hline $10 \# 1$ & 0.2370 & 0.0558 & 4.25 & 0.0000 & 0.1277 & 0.3463 \\
\hline \multicolumn{7}{|l|}{ TEN } \\
\hline $2-5$ years & 0.0269 & 0.0168 & 1.60 & 0.1100 & -0.0061 & 0.0599 \\
\hline$\geq 5$ years & 0.0909 & 0.0162 & 5.60 & 0.0000 & 0.0591 & 0.1227 \\
\hline \multicolumn{7}{|l|}{$\mathrm{KRU}^{\mathrm{c}}$} \\
\hline Rural & -0.1673 & 0.0132 & -12.69 & 0.0000 & -0.1931 & -0.1414 \\
\hline Urban & -0.1472 & 0.0142 & -10.34 & 0.0000 & -0.1752 & -0.1193 \\
\hline \multicolumn{7}{|l|}{ OCC\#GEN $^{b}$} \\
\hline $2 \# 1$ & 0.2448 & 0.0496 & 4.94 & 0.0000 & 0.1476 & 0.3420 \\
\hline $3 \# 1$ & 0.1131 & 0.0380 & 2.98 & 0.0030 & 0.0387 & 0.1876 \\
\hline
\end{tabular}


Table 5 (conclusion)

\begin{tabular}{|c|c|c|c|c|c|c|}
\hline Explanatory variable & Coefficient & Std. Error & $t$ statistic & $P>|t|$ & \multicolumn{2}{|c|}{ 95\% Conf. Interval } \\
\hline $4 \# 1$ & 0.0637 & 0.0227 & 2.81 & 0.0050 & 0.0193 & 0.1081 \\
\hline $5 \# 1$ & 0.0903 & 0.1024 & 0.88 & 0.3770 & -0.1103 & 0.2910 \\
\hline $6 \# 1$ & 0.4443 & 0.0474 & 9.37 & 0.0000 & 0.3514 & 0.5373 \\
\hline 7\# 1 & 0.0272 & 0.0750 & 0.36 & 0.7170 & -0.1198 & 0.1742 \\
\hline $8 \# 1$ & 0.2998 & 0.1470 & 2.04 & 0.0410 & 0.0116 & 0.5880 \\
\hline $9 \# 1$ & 0.1124 & 0.0214 & 5.24 & 0.0000 & 0.0704 & 0.1544 \\
\hline $10 \# 1$ & 0.1963 & 0.0571 & 3.43 & 0.0010 & 0.0842 & 0.3083 \\
\hline Constant & 10.8079 & 0.1639 & 65.96 & 0.0000 & 10.4867 & 11.1291 \\
\hline \multicolumn{7}{|l|}{ Summary statistics } \\
\hline No. observations & 7.150 & & & & & \\
\hline$F(52,7097)$ & 99.04 & & & & & \\
\hline Prob $>F$ & 0.0000 & & & & & \\
\hline$R^{2}$ & 0.4675 & & & & & \\
\hline Adjusted $R^{2}$ & 0.4636 & & & & & \\
\hline Root mean square error & 0.4435 & & & & & \\
\hline Akaike information criterion & 8716.73 & & & & & \\
\hline
\end{tabular}

Source: prepared by the author on the basis of data from the Jamaica Labour Force Survey, second quarter, 2004 to 2007, Statistical Institute of Jamaica (STATIN).

Notes: the dependent variable is the log of gross annual earnings from the worker's main job (LAE). Explanatory variables are the year; the main industry group (IND); the worker's main occupation group (OCC); regular hours worked per week (HWKD); the size of the employer, measured as the number of persons employed at the worker's main workplace (ES); years of experience (EXP); whether the worker's educational attainment was sufficient for matriculation in tertiary studies (TMAT); years of effective schooling (YS); whether the worker has received formal on-the-job training (OJT); tenure or time in the current job (TEN); whether the workplace is located in the capital Kingston, a rural area or an urban area (KRU); and interaction dummy variables.

a The first major occupation group- armed forces- has no private sector observations.

b The \# sign represents the interaction between the variables in question.

c Kingston Metropolitan Area (KMA) is the excluded category.

\section{Assessing the validity of labour quality explanation}

Table 5 shows that after accounting for measured human capital and other worker characteristics, both of the firm-size intercept-shift parameters are significant and greater than zero $\left(\alpha_{k}>0\right)$. Firms with 10 to 49 employees and firms with 50 or more employees are estimated to pay a premium (ESP) of $14.3 \%$ and $22.9 \%$, respectively, relative to the wages paid by firms with fewer than 10 employees (excluded category). The predicted ESPs are similar to the average differentials of $10.3 \%$ (10-49 workers) and $24.6 \%$ (50 workers or more) in table 3, where hours worked and occupation (four-digit code) were the only controls.

Accounting for labour quality therefore does not eliminate the ESWD. The source of ESWD cannot be explained by the observed measures of labour quality.

\section{Tenure profiles}

The seeming inability of the labour quality explanation (LQE) to account for the ESWD necessitates the evaluation of alternative explanations. One alternative that is testable within the context of the variables collected in the JLFS is the difference in tenure profiles. To assess the validity of the hypothesis that firm-size differences in tenure profiles are the cause of the observed firmsize wage premium (ESP), equation (1) was modified by interacting employer size $\left(E S_{k}\right)$ with the categorical variable $\left(\mathrm{TEN}_{l}\right)$, after which the size and significance of the employer-size $\left(E S_{k}\right)$ intercept-shift parameter $\alpha_{k}$ was reassessed. Figure 2 shows the estimated tenure profiles for firms with fewer than 10 employees, 10-49 employees and 50 or more employees. ${ }^{16}$ The location of the predicted return for the average worker in each of the three employer-size categories is indicated by the respective shapes, with the extensions at either end indicating the range of the $95 \%$ confidence interval. As figure 2 shows, the employer sizes have differing estimated tenure profiles over the ranges under consideration, and workers' remuneration increases with tenure. ${ }^{17}$ The

\footnotetext{
16 The estimated tenure profiles were derived from the estimates of the modified equation (1).

17 For each employer size, statistical tests suggest (at the 2\% level) that the predicted return at five years or more is higher than at two years or less.
} 
FIGURE 2

Tenure profiles by firm size

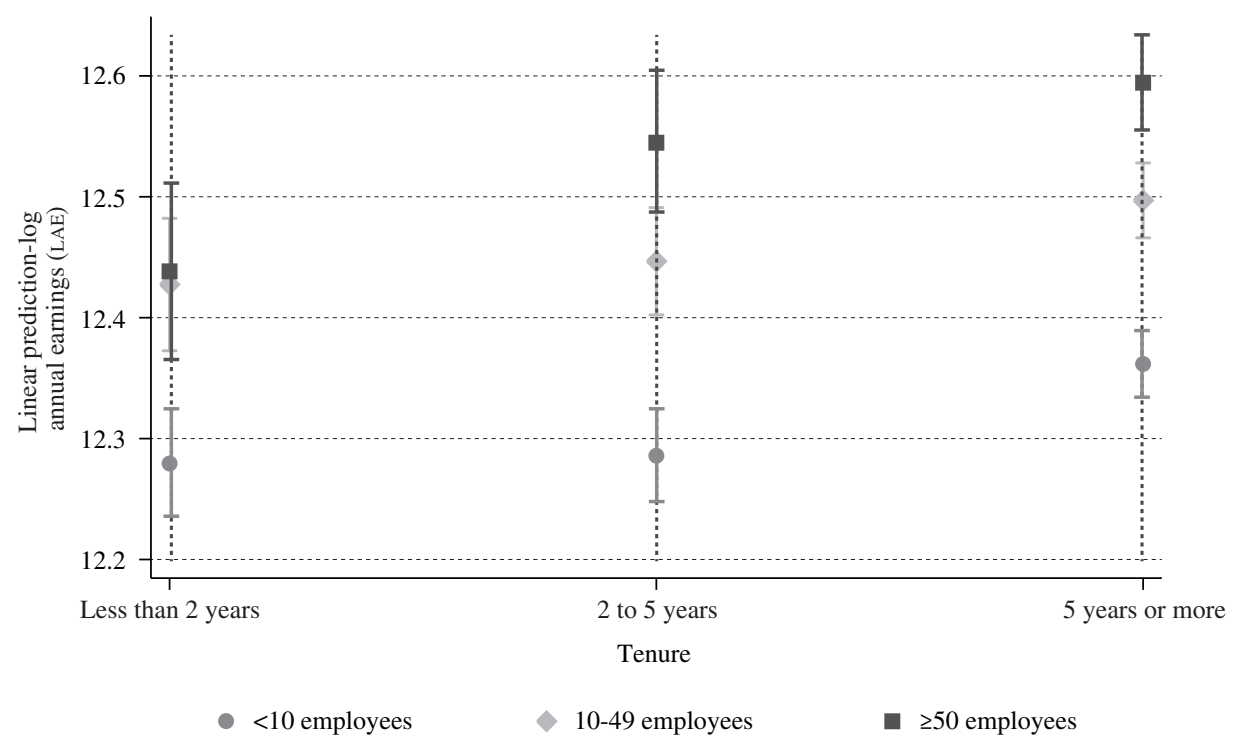

Source: prepared by the author on the basis of data from the Jamaica Labour Force Survey, second quarter, 2004 to 2007, Statistical Institute of Jamaica (STATIN).

Note: $95 \%$ confidence intervals.

difference in worker remuneration (returns) between a firm with 50 workers or more and one with fewer than 10 workers is smallest at the lowest measured tenure level and increases over this amount at higher tenure levels. ${ }^{18}$ This observation is to some extent consistent with the main thesis of the tenure profile explanation of ESWD. However, the fact that the returns for small firms at the lowest tenure level is statistically distinct from the returns for large firms may suggests that tenure profiles alone do not fully explain the ESP.

Table 6 examines whether average tenure differs by employer size. The average number of years in the current job is calculated by using midpoints in the bounded categories and the lower bound in the case of the unbounded category. ${ }^{19}$ The table suggests that workers in the smallest and the largest ES categories have stayed longer, on average, with their current employers than those in establishments with 10 to 49

18 The differences in the range between predicted returns for 50 workers or more and for fewer than 10 workers at the lowest level of tenure is statistically smaller than the range at the other tenure levels.

19 The original seven-category variable was used for this calculation. workers. ${ }^{20}$ The tenure profiles observed in figure 2 are not sufficient to explain the phenomenon shown in table 6. Why would workers, on average, stay longest with employers that reward them the least (small firms) for their years of service? The condition of work hypothesis may possibly provide an explanation for this anomaly.

Having established that tenure profiles differ by employer size, is it possible that size differentiated tenure profiles explain the employer size premiums (ESP) estimated previously? Table 7 presents the estimated $\alpha_{k}$ (the intercept-shift parameter associated with employer size $k$ ) for the size-tenure augmented model as well as those estimated in the original model. While accounting for tenure profiles reduced the wage premium to workers in establishments with 50 or more employees from approximately $22.8 \%$ to $15.9 \%$, it has not resulted in a reduction in premium paid to workers in firms with 10 to 49 employees.

The returns to education, experience and hours worked have not changed in a qualitative sense compared to the results from the original model.

\footnotetext{
20 Approximately $63 \%$ of the sample is contained in the last tenure category (five years or more). The accuracy of the mean years of tenure may be somewhat compromised by not being able to observe the distribution of such a large percentage of the sample.
} 
TABLE 6

Mean years in current job by employer size

\begin{tabular}{|c|c|c|c|c|c|}
\hline \multirow{2}{*}{ Firm size } & \multicolumn{2}{|c|}{ Average years in current job } & \multicolumn{3}{|c|}{ Statistically different from (one-tailed $p$ value) } \\
\hline & Mean & Std. Error & $<10$ employees & 10-49 employees & $\geq 50$ employees \\
\hline$<10$ employees & 4.159204 & 0.0213201 & & 0.0130 & 0.2951 \\
\hline 10-49 employees & 4.079413 & 0.0290760 & 0.0130 & & 0.1237 \\
\hline$\geq 50$ employees & 4.135558 & 0.0386143 & 0.2951 & 0.1237 & \\
\hline
\end{tabular}

Source: prepared by the author on the basis of data from the Jamaica Labour Force Survey, second quarter, 2004 to 2007 , Statistical Institute of Jamaica (STATIN).

TABLE 7

Size-tenure impact on firm-size wage differentials

\begin{tabular}{lccc}
\hline Firm size $\left(E S_{k}\right)$ & $\begin{array}{c}\text { Model II: } \\
\text { Size-tenure profile }\left(\alpha_{k}\right)\end{array}$ & $\begin{array}{c}\text { Model I: } \\
\text { Original }\left(\alpha_{k}\right)\end{array}$ & $\begin{array}{c}\text { H0: II }=\mathrm{I} \\
\text { (one-tailed } p \text { value })\end{array}$ \\
\hline 10 to 49 employees & $0.1479^{\mathrm{a}}$ & $0.1432^{\mathrm{a}}$ & 0.8735 \\
50 or more employees & $0.1588^{\mathrm{a}}$ & $0.2285^{\mathrm{a}}$ & 0.0690 \\
Summary statistic & & & 0.4675 \\
$\mathrm{R}^{2}$ & 0.4679 & 0.4636 & 8716.73 \\
Adjusted $\mathrm{R}^{2}$ & 0.4637 & 8719.68 & \\
Akaike information criterion & 873 & \\
\hline
\end{tabular}

Source: prepared by the author on the basis of data from the Jamaica Labour Force Survey, second quarter, 2004 to 2007, Statistical Institute of Jamaica (STATIN).

a Statistically significant at the $1 \%$ level or lower.

\section{V}

\section{Conclusions}

The positive correlation between wages and firm size and its implications for labour market theory and the theory of the firm take on added practical significance in the context of the high unemployment and the highly skewed income distribution that characterize Jamaica and much of the Caribbean. This paper estimates that after controlling for measured human capital and other characteristics, premiums of $14.3 \%$ and $22.8 \%$ are paid to workers in establishments with 10 to 49 employees and with 50 or more employees, respectively, relative to employees in firms with fewer than 10 employees.

The paper also indicates that worker remuneration may, on average, differ by as much as $29.8 \%$ across industry groups (one-digit level). However, the positive (negative) correlations between the largest (smallest) employer size category and industry wage premium suggest the possibility that employer-size wage differentials (ESWD) may be causal to inter-industry wage differentials in Jamaica.

The available evidence seems to suggest that employer-size premiums (ESP) persist after accounting for measured aspects of labour quality. Firm-size differences in tenure profiles, however, seem to provide a partial explanation to the estimated ESP in Jamaica. The ESP associated with the largest employers is reduced to $15.9 \%$, while there is no reduction in the premium paid by the mid-sized firms. There is no statistical difference in the average years of tenure between the largest and smallest size categories. This phenomenon, along with size of the unexplained premiums, opens the door to other theoretical explanations for the firm-size wage premiums, such as work conditions, union avoidance and efficiency wage, none of which can be tested with the currently available data.

In addition to the data limitation identified above, the manner in which existing variables in the JLFS data set are measured may affect the exploration of the ESWD phenomenon. The tenure variable (TEN), for example, is measured in a categorical manner in the JLFS, with over $60 \%$ of private sector workers belonging to the last category (that is, tenure of five years or more), which limits the variability that may be captured. Further exploration of 
the tenure profile hypothesis would therefore require a more continuous measure of worker tenure, specifically an expansion of what is currently the last category.

Finally, the implication of the ESWD phenomenon for the income distribution is a major motivator for its further investigation. Beyond this, the exploration of ESWD is fundamental to understanding how labour markets function. The motivations that determine firms' wage and employment decisions affect the nature of the labour market interventions that should be devised to tackle the persistently high levels of unemployment that are characteristic of Jamaica and much of the Caribbean.

\section{Bibliography}

Akerlof, G.A. (1984), "Gift exchange and efficiency-wage theory: four views", American Economic Review, vol. 74, No. 2, Nashville, Tennessee, American Economic Association.

(1982), "Labour contracts as a partial gift exchange", Quarterly Journal of Economics, vol. 97, No. 4, Oxford, Oxford University Press.

Antos, J.R. (1983), "Union effects on white-collar compensation", Industrial and Labor Relations Review, vol. 36, No. 3, Cornell University.

Arbache, J.S. (2001), "Wage differentials in Brazil: theory and evidence", Journal of Development Studies, vol. 38, No. 2, Taylor \& Francis.

Brown, C. and J. Medoff (1989), "The employer size-wage effect", Journal of Political Economy, vol. 97, No. 5, Chicago, The University of Chicago Press.

Bulow, J.I. and L.H. Summers (1986), "A theory of dual labor markets with application to industrial policy, discrimination, and Keynesian unemployment", Journal of Labor Economics, vol. 4, No. 3, Chicago, The University of Chicago Press.

Cousineau, D. and S. Chartier (2010), "Outliers detection and treatment: a review", International Journal of Psychological Research, vol. 3, No. 1, Medellin, University of San Buenaventura.

Duncan, G.J. and F.P. Stafford (1980), "Do union members receive compensating wage differentials?", American Economic Review, vol. 70, No. 3, Nashville, Tennessee, American Economic Association.

Fakhfakh, F. and F. Fitzroy (2006), "Dynamic monopsony: evidence from a French establishment panel", Economica, vol. 73, No. 291, London, London School of Economics and Political Science.

Filer, R.K. (1985), "Male-female wage differences: the importance of compensating differentials", Industrial and Labor Relations Review, vol. 38, No. 3, Cornell University.

Gittleman, M. and E.N. Wolff (1993), "International comparisons of inter-industry wage differentials", Review of Income and Wealth, vol. 39, No. 3, Wiley.

Hamermesh, D.S. and J. Grant (1979), "Econometric studies of labor-substitution and their implications for policy", Journal of Human Resources, vol. 14, No. 4, Wisconsin, University of Wisconsin Press.

Krueger, A.A. and L.H. Summers (1987), "Reflections on the interindustry wage structure", Unemployment and the Structure of Labor Markets, K. Lang and J. Leonard (eds.), Oxford, Basil Blackwell

Lazear, E.P. (1981), "Agency, earnings profiles, productivity, and hours restrictions", American Economic Review, vol. 71, No. 4, Nashville, Tennessee, American Economic Association. (1979), "Why is there mandatory retirement?", Journal of Political Economy, vol. 87, No. 6, Chicago, University of Chicago Press.

Lester, R. (1967), "Pay differentials by size of establishment", Industrial Relations, vol. 7, No. 1, Wiley.

Main, B.G.M. and B. Reilly (1993), "The employer size-wage gap: evidence for Britain", Economica, vol. 60, No. 238, Wiley.
Masters, S.H. (1969), "An interindustry analysis of wages and plant size", Review of Economics and Statistics, vol. 51, No. 3, Cambridge, Massachusetts, The MIT Press.

Mellow, W. (1982), "Employer size and wages", Review of Economics and Statistics, vol. 64, No. 3, Cambridge, Massachusetts, The MIT Press.

Mounsey, A. and T. Polius (2011), "Trinidad and Tobago: inter-industry wage differentials", CEPAL Review, No. 105 (LC/G.2508-P), Santiago, Chile.

Oi, W. (1983), "The fixed employment costs of specialized labour", The Measurement of Labour Cost, J.E. Triplett (ed.), Chicago, University of Chicago Press.

Oosterbeek, H. and M. van Praag (1995), "Firm-size wage differentials in the Netherlands", Small Business Economics, vol. 7, No. 3, Springer.

Osborne, J.W. and A. Overbay (2004), "The power of outliers (and why researchers should always check for them)", Practical Assessment, Research \& Evaluation, vol. 9, No. 6.

Pearce, J.E. (1990), "Tenure, unions, and the relationship between employer size and wages", Journal of Labor Economics, vol. 8, No. 2, Chicago, The University of Chicago Press.

Riveros, L.A. and L. Bouton (1994), "Common elements of efficiency wage theories: what relevance for developing countries", Journal of Development Studies, vol. 30, No. 3, Taylor \& Francis.

Rosen, S. (1982), "Authority, control, and the distribution of earnings", Bell Journal of Economics, vol. 13, No. 2, Santa Monica, California, RAND Corporation.

Salop, S.C. (1979), "A model of the natural rate of unemployment", American Economic Review, vol. 69, No. 1, Nashville, Tennessee, American Economic Association.

Schmidt, C. and K.F. Zimmermann (1991), "Work characteristics, firm size and wages", Review of Economics and Statistics, vol. 73, No. 4, Cambridge, Massachusetts, The MIT Press.

Shapiro, C. and J.E. Stiglitz (1984), "Equilibrium unemployment as a worker discipline device", American Economic Review, vol. 74 No. 3, Nashville, Tennessee, American Economic Association.

Slichter, S. (1950), "Notes on the structure of wages", Review of Economics and Statistics, vol. 32, No. 1, Cambridge, Massachusetts, The MIT Press.

Smith, A. (1904), An Inquiry into the Nature and Causes of the Wealth of Nations, London, Methuen \& Co. [online] http://www.econlib. org/library/Smith/smWN4.html.

Tan, H. and G. Batra (1997), "Technology and firm size-wage differentials in Colombia, Mexico, and Taiwan (China)", World Bank Economic Review, vol. 11, No. 1, Oxford, Oxford University Press.

Verardi, V. and C. Croux (2009), "Robust regression in Stata", The Stata Journal, vol. 9, No. 3.

Winter-Ebmer, R. and J. Zweimüller (1999), "Firm-size wage differentials in Switzerland: evidence from job-changers", American Economic Review, vol. 89, No. 2, Nashville, Tennessee, American Economic Association.

Zwick, T. (2009), "Why pay seniority wages?", ZEW Discussion Paper, No. 09-005, Mannheim, Centre for European Economic Research. 